\title{
Con los ojos en las pieles ${ }^{1}$
}

\author{
ANDRÉS INOCENTE MARTÍN HERNÁNDEZ
}

Andrés Inocente Martín Hernández é curador independente. Nasceu em Cuba, reside no Brasil (São Paulo) desde 1998. Possui graduação em Química, Instituto Superior Pedagógico Felix Varela, Cuba (1989). Mestrado em Artes Visuais, Faculdade Santa Marcelina, São Paulo (2010). Foi coordenador de exposições na Bienal de Havana, Cuba - Centro de Arte Contemporânea Wifredo Lam, (1994-1998), coordenador executivo do departamento de curadoria do MAM-SP (2005-2010) e coordenador de projetos da Luciana Brito Galeria (2011-2013). Atua nas áreas de curadoria, crítica de arte, produção editorial e museologia.

\footnotetext{
${ }^{1}$ Este texto fue publicado en el catálogo de las Metáforas Construidas, exposición realizada en la Galería La Cometa, Bogotá - Colombia, de 24 septiembre a 14 noviembre de 2015. 


\section{- RESUMEN}

Metáforas Construidas, exposición realizada en Bogotá, Colombia, donde se exhibieron obras de la artista brasileña Regina Silveira, seleccionadas a partir de una línea conceptual que relacionó el recorte cronológico de la producción de la artista en relación directa con el contexto arquitectónico del espacio expositivo. Esa relación direccional fue considerada en la inserción de los trabajos de otros cuatro artistas en la exposición. El texto destaca los diálogos y métodos utilizados para la concepción, construcción y discusión de la exposición.

\section{- PALABRAS CLAVE}

Artista, curador, espacio de exposición, la instalación pública.

\section{- ABSTRACT}

In Metáforas Construidas, exhibition held in Bogotá - Colômbia, works were presented brazilian artist Regina Silveira, selected from a conceptual line that linked the chronological cut of the artist's production in direct relation to the architectural context of the exhibition space . This adirectional relationship was also seen in the insertion of the work of four other artists in the exhibition. The text highlights the dialogues and methods used for the design, construction and exhibition discussion.

\section{- KEYWORDS}

Artist, Curator , exhibition space, installation , the public.

\section{Introducción}

Con los ojos en las pieles, es el texto crítico de la exposición Metáforas Construidas presentada en la galería La Cometa, Bogotá, en septiembre de 2015. En la muestra fueron presentadas obras de la artista visual Regina Silveira. La exposición fue concebida a partir de la invitación de la Galería para realizar una exhibición con obras que abarcaran la más reciente producción de artistas brasileños. El hecho de que Silveira sea la artista brasileña contemporánea más reconocida por sus aportes artísticos y pedagógicos en el escenario nacional e internacional, fue importante para establecer una relación obra-concepto espacio-público, e invitarla a participar en el proyecto. La muestra también incluye una representación concisa, pero abrangente, de obras de cuatro artistas de diferentes generaciones de arte brasileño. Estableciéndose así un diálogo conceptual entre todos los trabajos presentados.

Aquí se manifiesta la relación con los artistas, permitiéndole actualizarse sobre la producción de los mismos y su contexto; una relación sustentada en el respeto y la simpatía por las ideas y capacidades intelectuales de los artistas. Así fue construida una narrativa en torno a un tópico de intereses que se convirtió en texto curatorial de la propuesta. Esta narrativa de forma general está fundamentada en uno o varios argumentos que el curador compartió con el público a través de la lectura que jerarquiza y distingue el proyecto.

Para la curaduría, en cuestión, fue hecha una selección de obras, primeramente de la artista Regina Silveira, que se relacionaran entre sí y con el espacio expositivo, incluida la fachada de la Galería. Fueron escogidas diversas obras, que posteriormente a partir de una decantación conceptual, del hecho curatorial siempre 
selectivo, siempre excluyente, que llevó a una selección final. De aquí al espacio. Así surge Metáforas Construidas.

La experiencia curatorial me llevó a conectar las obras de arte con el espacio expositivo, haciendo que este último se integrase como elemento co-protagónico.

Otra cuestión relevante en la curaduría fue pensar en la relación con el público:

- La distribución de las obras, pensando no solo en ellas, sino también como el público podrá disfrutarlas de forma óptima.

-La definición del sentido de la circulación del público por la exposición, está condicionado en un determinado sentido.

- El tipo de relación del público con las obras, (más íntimo, con distanciamiento, complicidad, agresión, necesario para la complementación).

- Fueron incluidas obras de carácter lúdico memorables para "divertir" al público.

\section{Con los ojos en las pieles}

En el sinuoso y sorprendente trayecto del arte contemporáneo, la Bienal de La Habana ha cumplido una vez más con su función de punto de encuentro para discutir las variaciones radicales de lenguaje en la escena artística contemporánea, siempre lista para hacer proliferar nuevos proyectos. Fue en la 12ma edición de 2015 que germinó la muestra Metáforas construidas. El punto de partida fue realizar una exposición de Regina Silveira ${ }^{2}$ en la galería bogotana La Cometa, espacio construido y diseñado por el arquitecto Daniel Jaramillo y José Alejandro Bermudez en 2007. Silveira, con su agenda hipercompleta y su especial simplicidad, aceptó de buen grado preparar el evento y, aun con los contratiempos que suelen poner en riesgo la materialización de cualquier evento, es con enorme satisfacción que podemos, ahora, reposar nuestra mirada sobre las pieles sedosas, ásperas, jóvenes, viejas, seductoras, repulsivas, pero siempre contemporáneas, que son las obras de Metáforas construidas, proyecto único que se ha enriquecido con la inclusión de trabajos de otros cuatro artistas brasileños. Fotografías, proyecciones, performances, dibujos, instalaciones integran el conjunto de obras de la exposición individual de Regina Silveira, así como las de los artistas Andrey Zignnatto, Lucas Bambozzi, Lydia Okumura y Renato Pera en la muestra colectiva, presentadas simultáneamente en todas las salas de la galería. El conjunto de las piezas recrea un mundo de relaciones irreales, donde las metáforas son construidas en varias direcciones, transcritas en versiones del imaginario personal, convertidas en leyendas materialmente transformadas en "verdades" secuenciales, efímeras.

El eje temático de esta muestra son las metáforas de la realidad individual: el YO para y en el OTRO (artista y público); metáforas de la realidad cotidiana donde lo inverosímil y lo auténtico interactúan en un juego real de posibilidades subjetivas y/o materiales. Así, la representación de lo real procede con lo imposible,

\footnotetext{
${ }^{2}$ Es en mi contacto con el arte brasileño, desde mi experiencia inicial en el Centro Wifredo Lam en Cuba, y posteriormente en el Museo de Arte Moderno de São Paulo, que surge la posibilidad de trabajar con una de las artistas brasileñas más universales: Regina Silveira. A ella dejo aquí mi testimonio de gratitud, ya que tanto su obra como la de Cildo Meireles han sido fundamentales para la consolidación de mi crecimiento como curador. El profesionalismo, la competencia y la dedicación de Silveira han hecho posible, en suma, la construcción personal de mi trayectoria.
} 


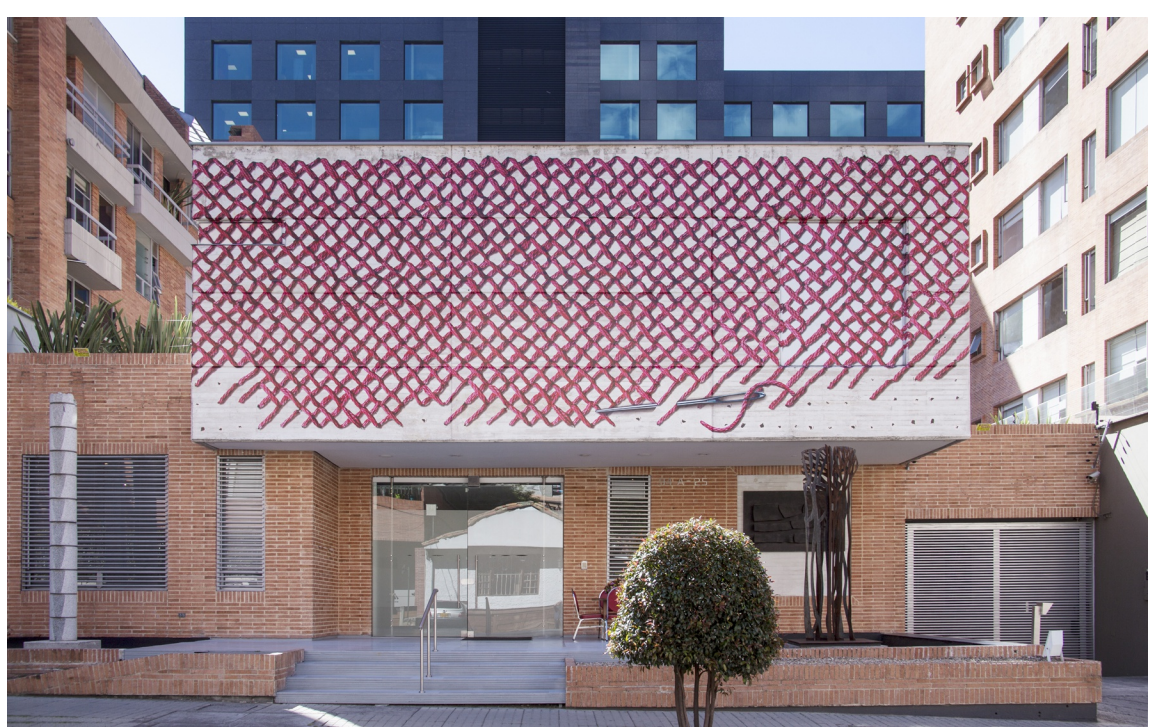

Figura 1. Regina Silveira, PINK TRAP, impresión y corte en vinilo adhesivo, 4,40 X 15 m, 2015. Fachada de la Galería La Cometa, 2015, Bogotá - Colombia. Fotografía: Juan Pablo Velasco.

materializado en una relación cíclica coherente e inteligentemente elaborada. Los elementos contenidos, citados y representados en las obras son puntos de conexión con el todo; deben ser observados e interpretados por los artistas como propuestas, y asimilados por parte del espectador como intersticios particulares constituyentes de una trama de asociaciones que operan como un todo. Esto es algo que podemos observar, en una escala mayor, en la diversidad de generaciones presente en esta exhibición, aunque se trate apenas de la obra de cinco artistas.

Aquí están nuestros ojos captando una geometría particular, algunas veces simulada, otras, implícita en fragmentos reales, en relecturas de contextos cotidianos, imaginados, sugeridos y forzados en sus relaciones. La maleabilidad de esta apropiación aborda las estructuras tradicionales como sugerencia y no como límite, de modo que es posible, entonces, a través de la representación de cada propuesta, fragmentar la geometría existente, al agregar formas lineares y convergentes, paralelas, o planos y superficies que llenan o vacían los contornos y los convierten en fragmentos llenos de nuevos significados que, una vez hilvanados, crean tramas que se contraen entre sí y se dilatan en el conjunto de las obras expuestas, convirtiendo el espacio de la galería - micro espacio de la metrópoli - en lo que Jonathan Raban denomina "el lugar en que el hecho y la imaginación simplemente tienen que fundirse". ${ }^{3}$

Como consecuencia de este proceso de inmersión pueden emerger entonces la sorpresa, la ilusión, la decepción, el optimismo, la protección o el deseo de pasar desapercibido, como opciones subjetivas y prácticas que las obras de esta exposición ofrecen. El espectador puede colocar en jeque la propia experiencia del artista, al tomar como suyas las referencias de éste. Al mismo tiempo, esto hace con que cada artista convierta sus motores utópicos en sensores reales, revelando así su fragilidad ante la evidencia de lo inusitado. Tales articulaciones se sirven del

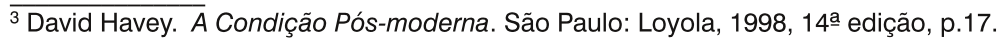




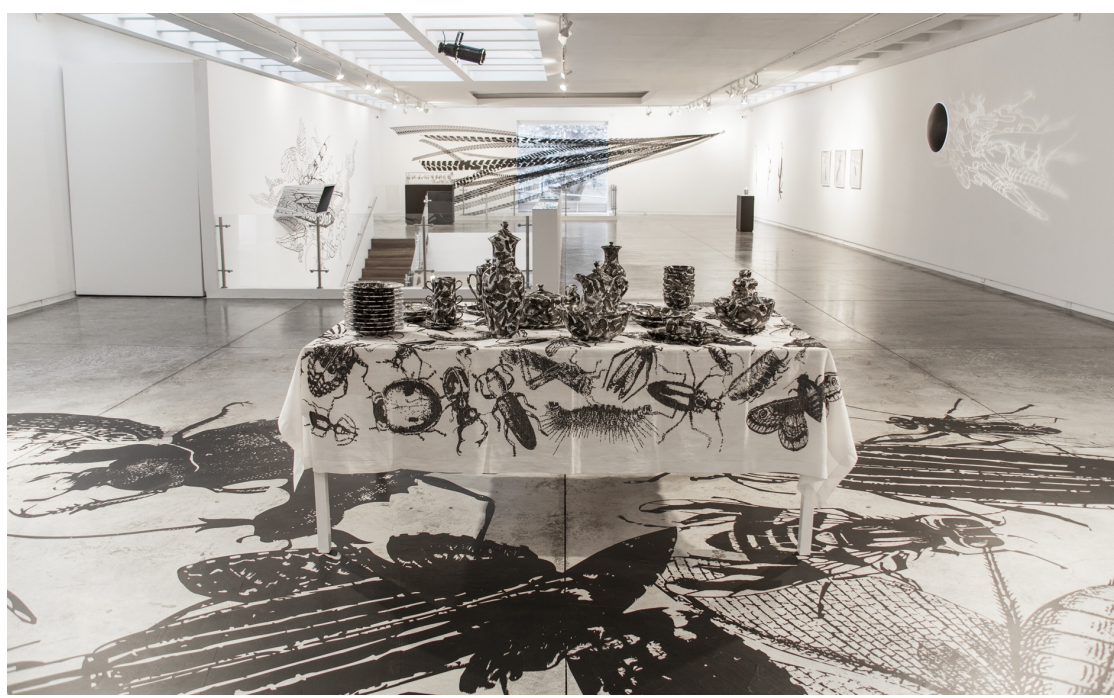

Figura 2. Regina Silveira. Vista parcial de la exposición Metáforas Construidas, Galería La Cometa, 2015, Bogotá - Colombia. Fotografía: Juan Pablo Velasco.

desplazamiento de situaciones, movimientos que también implican la ejecución de nuevas maniobras con materiales y productos singulares respecto a las convenciones artísticas, para que el resultado no sea similar a la pintura, ni a la escultura, por ejemplo. Los "objetos" se convierten en protagonistas de la narrativa, de suerte que el artista confisca objetos y espacios para establecer con ellos una conexión transitiva entre múltiples discursos.

Las "pieles" se van configurando a medida que varios agentes actúan sobre ellas, mediante procesos químicos que traslucen reacciones secuenciales, ocupando individualmente espacios físicos, o exportando nuestras utópicas convicciones para incluirlas en contextos de dialogo mutuo, tal y como aparece representado alegóricamente en Nómada (2012). Vamos así, multiplicando nuestra presencia, dejando vestigios de nuestras sombras. La concepción de Metáforas Construidas se ensambla como parte de este proceso.

Las sombras en las obras de Regina Silveira aparecen y desaparecen dentro de la lógica de la artista, la más pura manifestación del enigma que ellas contienen. Sombras: pero no espíritus melancólicos a nuestro alrededor, sino sombras sin miedo de ser degustadas, que se ofrecen para ser observadas y para que seamos observados por ellas, para que las examinemos como moscas, cucarachas, manos, agujas, objetos diversos. Todas, como Bucéfalo(s), en busca de una empatía relacional y racional con cada elemento, composición, estructura, conjunto, para pasar a interactuar y formar parte de las mismas, con una pulcritud amenazada por un juego discordante de recursos y soportes.

Entre los elementos predominantes en la selección de los trabajos expuestos tenemos la arquitectura y sus desdoblamientos, o las extensiones que llevan a la ocupación de la arquitectura, gestando, entre las interpretaciones evocadas, una nueva arquitectura, un nuevo espacio público, resaltando que no se trata apenas de la relevancia de la arquitectura, sino también de una propuesta de nexos del arte 
brasileño con el arte universal, argumento de la existencia de un arte único. En este caso, contamos con ejemplos de artistas relevantes cuya producción visual circula en contextos globales.

En Metáforas Construidas la semántica y fonética de la categoría artes plásticas es diluida, al incorporar lo visual como hegemónico. De las primeras hasta las más recientes técnicas para registrar la luz, el sonido, el movimiento, la velocidad, la temperatura, los virus orgánicos y/o digitales, las plagas transgénicas, la óptica. De la fotografía, el grabado, la escultura, el performance, el cine, la aeronáutica, la cosmonáutica y el satélite, hasta el laser, la digitalización, la internet y el celular: la plástica sustituida por lo visual y lo sonoro. Asuntos que se arrastran bajo la fuerza centrípeta de un impacto que los diluye en mezclas y ramificaciones imprevisibles.

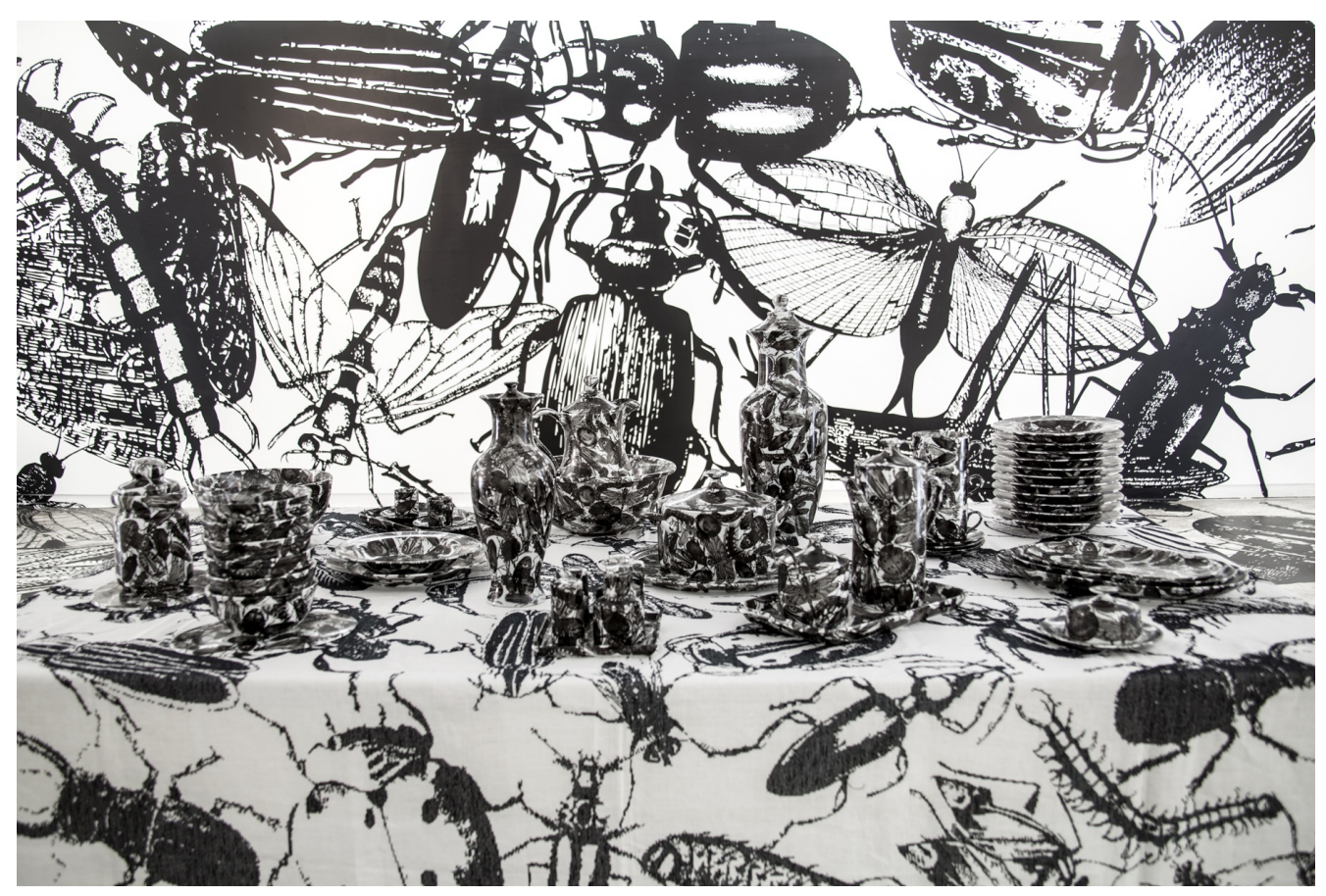

Figura 3. Regina Silveira. Vista parcial de las obras: Mundus Admirabilis, 2008, corte en vinilo adhesivo, dimensiones variables; y Rerum Nature, 2007-2008, porcelana sobrevidriada, lino bordado, madera y acero, 100×190x110 cm, Galería La Cometa, 2015, Bogotá - Colombia. Fotografía: Juan Pablo Velasco.

Ya he pensado que podría deglutir el espacio de La Cometa en forma de bizcocho. Metafóricamente, tendría la posibilidad de comer todo lo que ella significa. Es esa una de las sensaciones que provoca el performance Biscoito Arte (1976) de Regina Silveira, contextualizado con dos fotografías de época (1976/1997), una de la artista comiendo el bizcocho y otra del bizcocho en un plato con los tres cubiertos. Biscoito Arte nos da la posibilidad de comer todo o casi todo lo que el arte significa y representa para cada uno de nosotros, es el poder sadomasoquista de dominar lo que nos imponen y tratan de explicarnos. Es la respuesta a lo el otro nos impone como "alimento". Sobre todo, exalta el papel social del arte en cualquier contexto. 
Es proceso, objeto y símbolo, igual que las copas, la aguja, el carro, las marcas de las ruedas, el gancho, el metal, el edificio: lo imaginado y lo realizado. iEs movimiento!

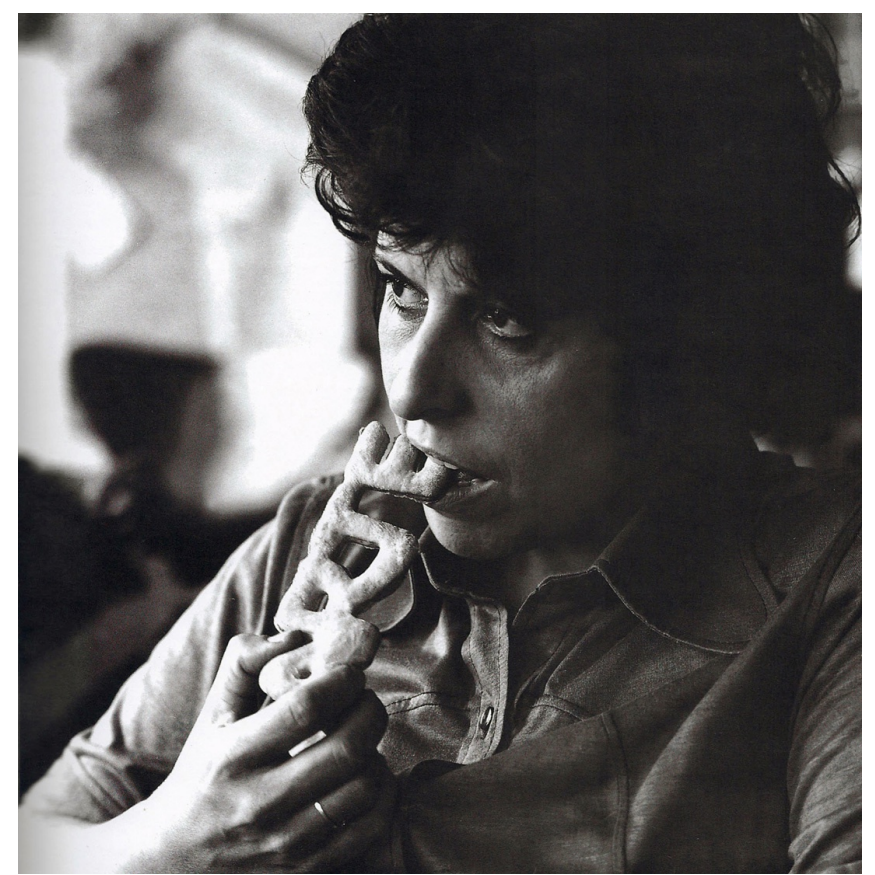

Figura 4. Regina Silveira, Del díptico Biscoito de Arte, 1976. Fotografía: Gerson Zanini.

Las líneas y los planos externos e internos que configuran la composición plástica y visual engendran contornos y estructuras que se mezclan con los ya existentes, los cuales fecundan estructuras híbridas con nuevas equivalencias. En Sin Título (bordado rosado), (2015), el vinil adhesivo simula una aguja cociendo toda la fachada de La Cometa. Así, el hecho inconcebible de que la aguja atraviese las paredes de concreto se desdobla en argumento literal de la acción, y es sustituido por un énfasis en la alegoría de la acción, en el misterio de la posibilidad y en la exaltación y en la forma de concebir y concretizar dicha operación plástica. En este artificio de obra pública concebido por Regina Silveira, la costura y la aguja se encuentran incorporados a los elementos arquitectónicos, manteniendo las proporciones agigantadas y omitiendo parte de ellos, como un óleo temporal sobre una tela permanente. De esta forma se integran al edificio, estableciendo que los elementos "cosidos" solamente prestan su superficie y contorno a la intrusa que los cegó. Ya en la serie Tramada (2015) la aparente maleabilidad del soporte inmoviliza, a través de una costura simulada y bidimensional, la movilidad y funcionalidad de los objetos (revólver, martillo, hacha) en una representación sarcástica y crítica.

Ya en El Arte de diseñar (1982), la marca de la mano de la artista está plasmada de forma irónica en el diálogo entre las imágenes que muestran las interacciones del proceso gráfico con otros procedimientos de producción plástica. Las imágenes de esta obra fueron realizadas sobre las hojas de un cuaderno académico de dibujo. La artista introduce en este caso, la silueta en perspectiva de un revól- 
ver, adecuado a la anatomía de una de las manos en cada hoja. El arma de fuego es acariciada gráficamente, no en su función de defensa y ataque, sino con ternura y sensualidad, como una caricia. Tales estrategias para satirizar lo representado aparecen también en los vídeos El arte de diseñar (1980) y Una vez más (2013), considerando que los soportes y las maniobras estéticas y conceptuales, aunque son diferentes, se sostienen en un discurso crítico que subvierte el significado original para, de forma irónica, materializar una nueva enunciación.
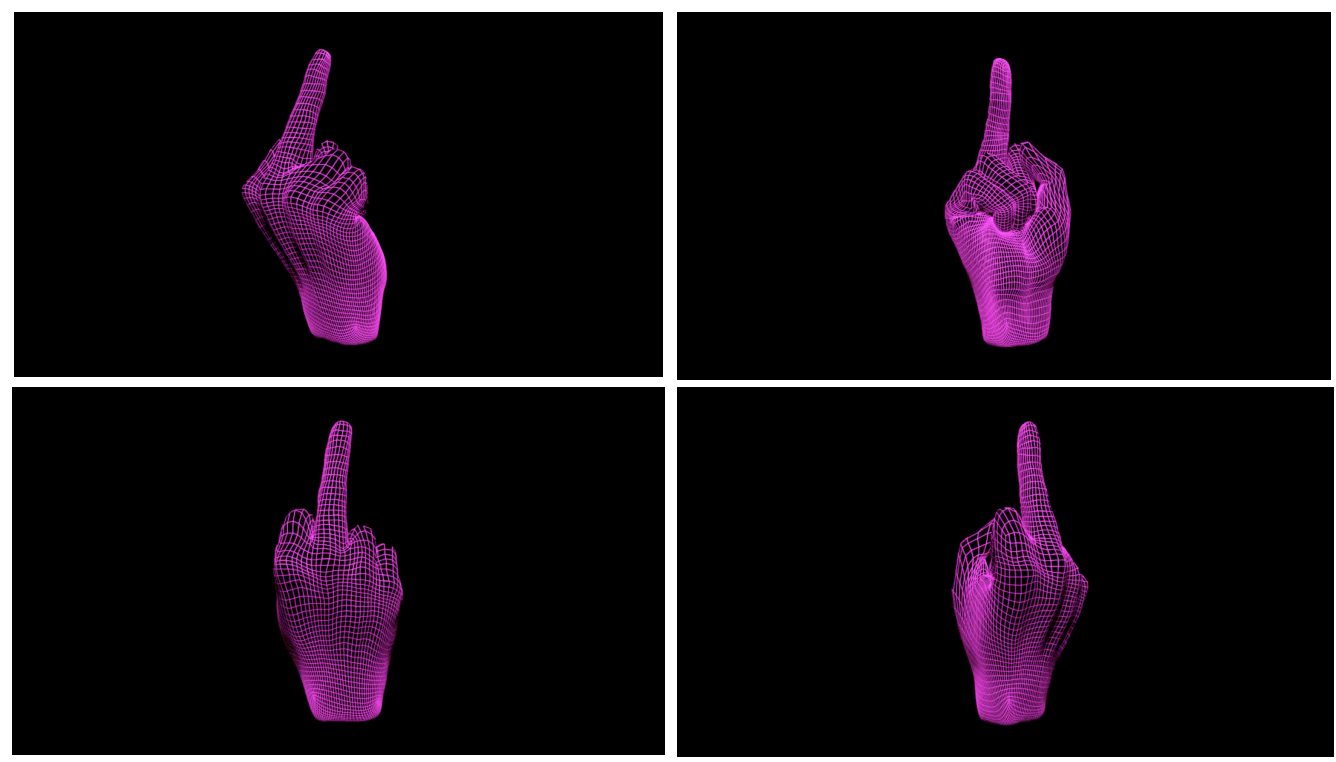

Figura 5. Regina Silveira, frames de Una vez más, animação digital, duración 2:56 min (loop), 2012. Modelo digital: Alfio Presutti.

En las obras Touch \#4 (2013) y Dreamer 2 (2013) aparecen las manos. En la primera de forma gigante, totalmente fuera de escala y creando esa duda sobre qué es lo que está fuera de escala: ¿las imágenes o el espectador? En la segunda se trata de impresiones digitales grabadas sobre copas de cristal en tamaño real. En ambas, las manos se presentan, en palabras de la propia Silveira, con "el deseo de ser signos de presencia y de identidad con la capacidad de designar otra relación entre el signo y el cuerpo". En la serie Plugged (2001), la mano aparece ahora en una operación sugerida de riesgo, corroborado a partir de un movimiento congelado; en la relación del símbolo con la acción recurrente sobre elementos comunes que remiten a otro símbolo. 

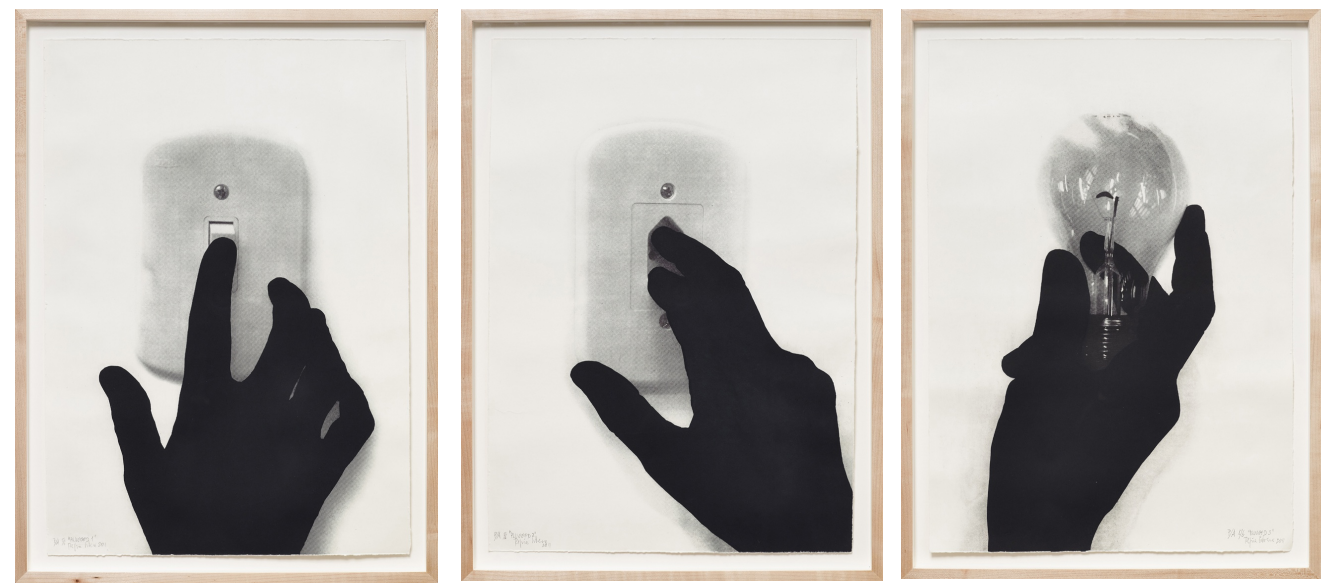

Figura 6. Regina Silveira, Plugged 1, Plugged 2 e Plugged 3, fotograbado, 2011, 66,5 x 47,5 $\mathrm{cm}$. Fotografía: Eduardo Verderame.

En Alfinete, de la serie Armarinhos (2001) se alteran la inocencia, la delicadeza y neutralidad de la porcelana blanca, al proyectar sobre el utensilio doméstico la silueta negra de un alfiler, objeto agresivo y punzante al cual se le ha atribuido una nueva función. Así, el soporte es un objeto común cuya intensidad aséptica e ingenua es explorada. Esta relación también está presente en la porcelana sobrevidriada de Rerum Naturae (2007/2008). Una plaga perversa, paranoica y alusiva parece amenazar la tranquilidad, la fluidez, la transparencia, y la ecuanimidad que el suporte inocuo de la porcelana representa, instalado sobre un mantel de lino, pulcro en su germen, ahora invadido en todos los radios de la instalación por insectos gigantes: plagas que infectan, rarificadas, mimetizadas, amorfas y transgénicas, intolerantes, rígidas, descaradas, ciegas y estáticas, monumentales, donde la escrupulosidad del lino y de la cerámica blanca se lamentan sin defensa de la crueldad híbrida y sarcástica representada, para crear un Mundus Admirabilis (2008) único, sombrío e inhabitable, tal vez inevitable.

Se trata, ahora, de otra explosión de imágenes, luces y sombras incoherentes, imposibles, irónicas, en las obras Umbral (2011) y Escape (2014). En la primera, la variedad de imágenes sobrepuestas de forma discordante y forzada en el vinil explotan en la caja de madera pintada como fuerza mágica que retuvo, en el interior de su vientre, una cantidad de hijos imposibles en su vientre. En la segunda, esa imposibilidad posible es forzada por una matriz circular que engendra arquetipos inverosímilmente representados para aquella situación. Aquí las imágenes surgen a partir de la radiación electromagnética que puede ser percibida por el ojo humano, la luz visible. En ambas estallan las imágenes de huesos tallados, las imágenes en siluetas, los monstruos terrenos que transportaban a los señores mayas al inframundo; las imágenes de las conchas talladas o de las de las vasijas pintadas al estilo de los códices mayas del período clásico tardío. ${ }^{4}$

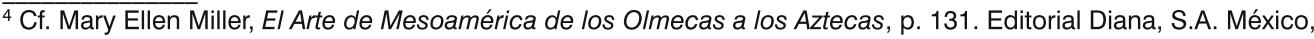
1998. 


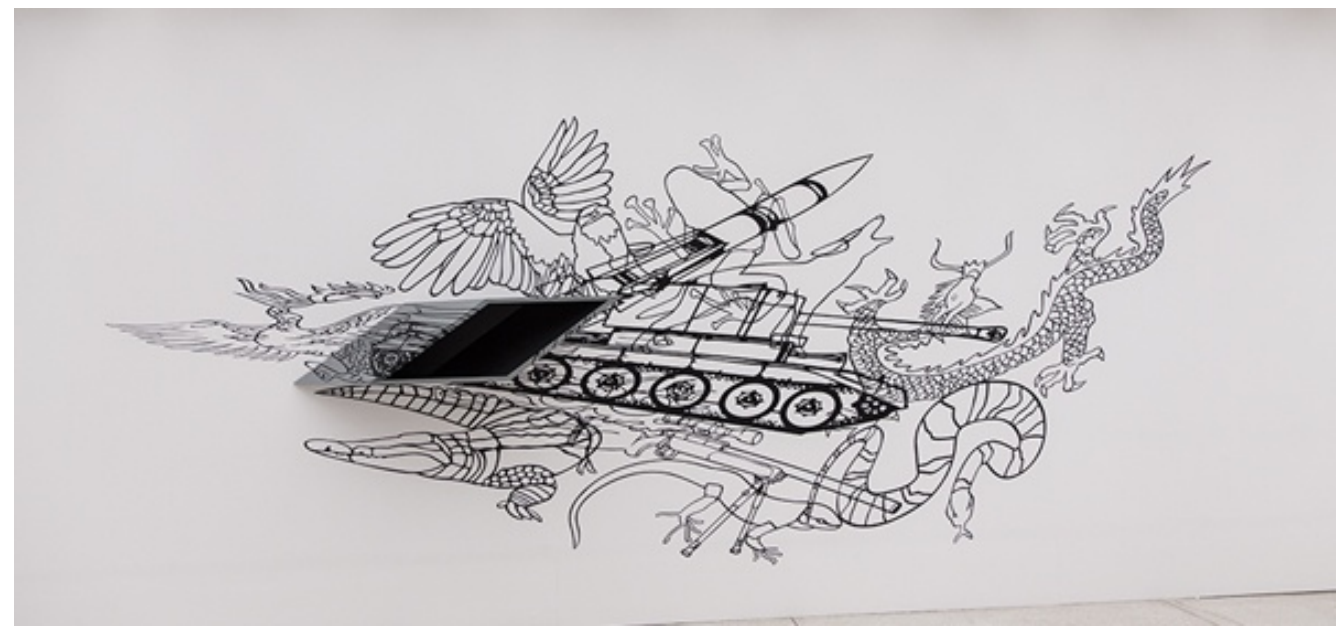

Figura 7. Regina Silveira, Escape, 2014, pintura industrial sobre madera, vinilo adhesivo recortado, $40 \times 44 \times 166 \mathrm{~cm}$. Fotografía: Juan Pablo Velasco.

Si en Transit (2001) se repiten las sombras a partir de la proyección del desplazamiento de una mosca gigante sobre la arquitectura local y el espacio público, en alusión a una intrusa asimétrica e híbrida para los patrones domésticos, moldeada y moldeable, capaz de enfrentar las cartografías estructurales inéditas, en Track Series (Featherdust) (2005), las sombras son materialmente estáticas, alusivas y desproporcionales a las marcas de las ruedas del pequeño carro de madera. Un carro sin motor y estructura de un potente $4 \times 4$, pero capaz de moverse sobre las paredes de la sala de exposición, dejando sus marcas gigantes con un poder gráfico y sensorial, absoluto y dominador, estructurando así un conjunto compositivo desbordante de sarcasmo.

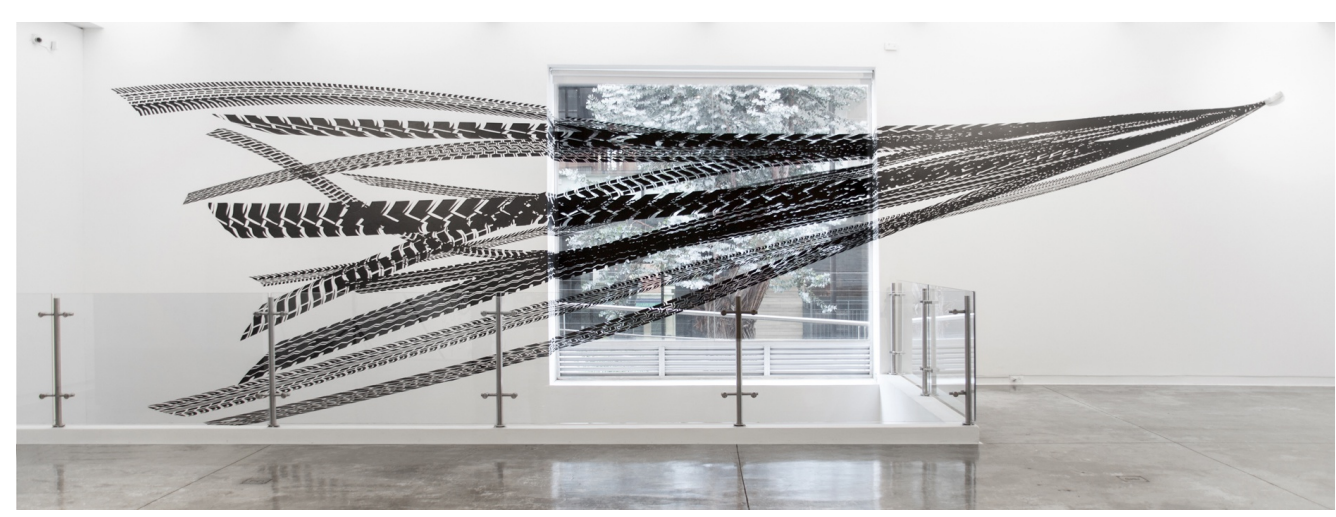

Figura 8. Regina Silveira, Featherdust, 2005/15, recorte en vinilo adhesivo y juguete de madera, 3,05 x 10,15m. Exposición Metáforas Construidas. Galería La Cometa, 2015, Bogotá - Colombia. Fotografía: Juan Pablo Velasco. 
Nuevamente en Voodoo, serie de 2015, los objetos incisivos, como lascas agresivas, cortantes, proyectan sus sombras en un movimiento del símbolo que relaciona el efecto y su causa, ocultando un ciclo indefinido que busca identificar cuál es la operación inicial. Las seis operaciones (incluyendo el soporte, la máquina y el artista) constituyen el antes y el después sin un orden establecido hegemónicamente, en un contraste real de violencia, irónicamente representada.

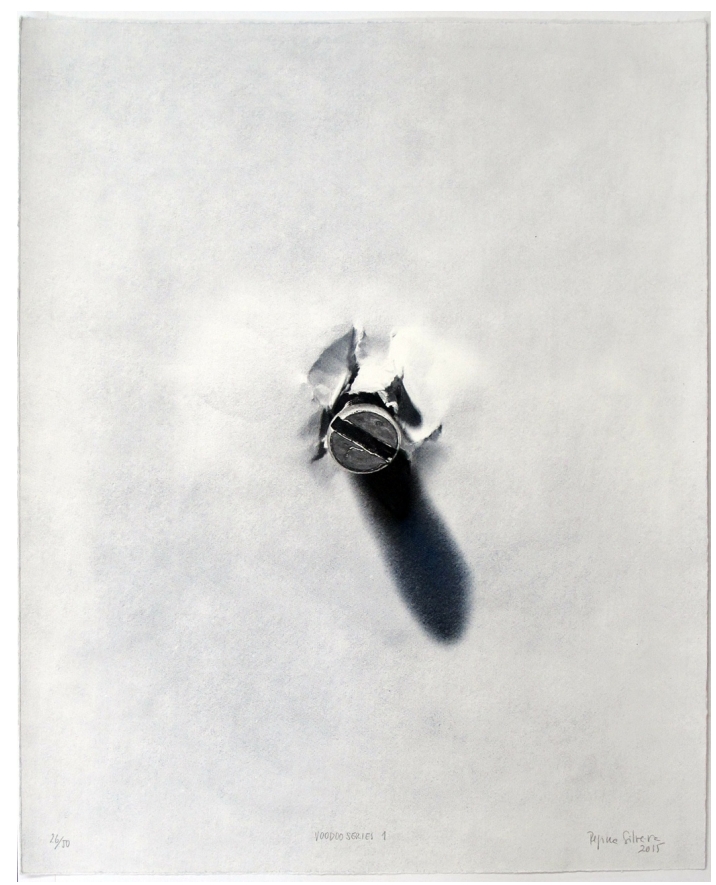

Figura 9. Regina Silveira, Voodoo Series 1, fotograbado, $70 \times 50 \mathrm{~cm}$. Fotografía: Eduardo Verderame.

Así, comparto con el crítico y curador brasileño Agnaldo Farias, la idea de que:

la singularidad de la obra de Regina Silveira reposa en el modo como actualiza y discute dos proposiciones básicas del pensamiento moderno, forjadas con el propósito de facultar ese retorno: la geometría analítica de Descartes, instancia pretensamente segura de modelación de lo visible, y, en el campo de las artes plásticas, la perspectiva lineal, método creado en el Renacimiento y colocado en crisis en el siglo XIX, utilizado para la representación del espacio. ${ }^{5}$

$\overline{5}$ In Catálogo de la exposición Regina Silveira, desenhos no AS Studio, São Paulo, Brasil, 1995. 


\section{...y otras muchas metáforas...}

Para la obra In Front of Light, 1977/ 2015, Okumura construye un enmarañado radiográfico tridimensional en el que utiliza vidrios, cuerdas, pintura y rayaduras con graphite en el piso de la sala. Son entonces el piso, el desplazamiento del espectador y sobre todo la luz, elementos que, a su vez, inciden sobre el espacio donde está la instalación y componen la instalación.

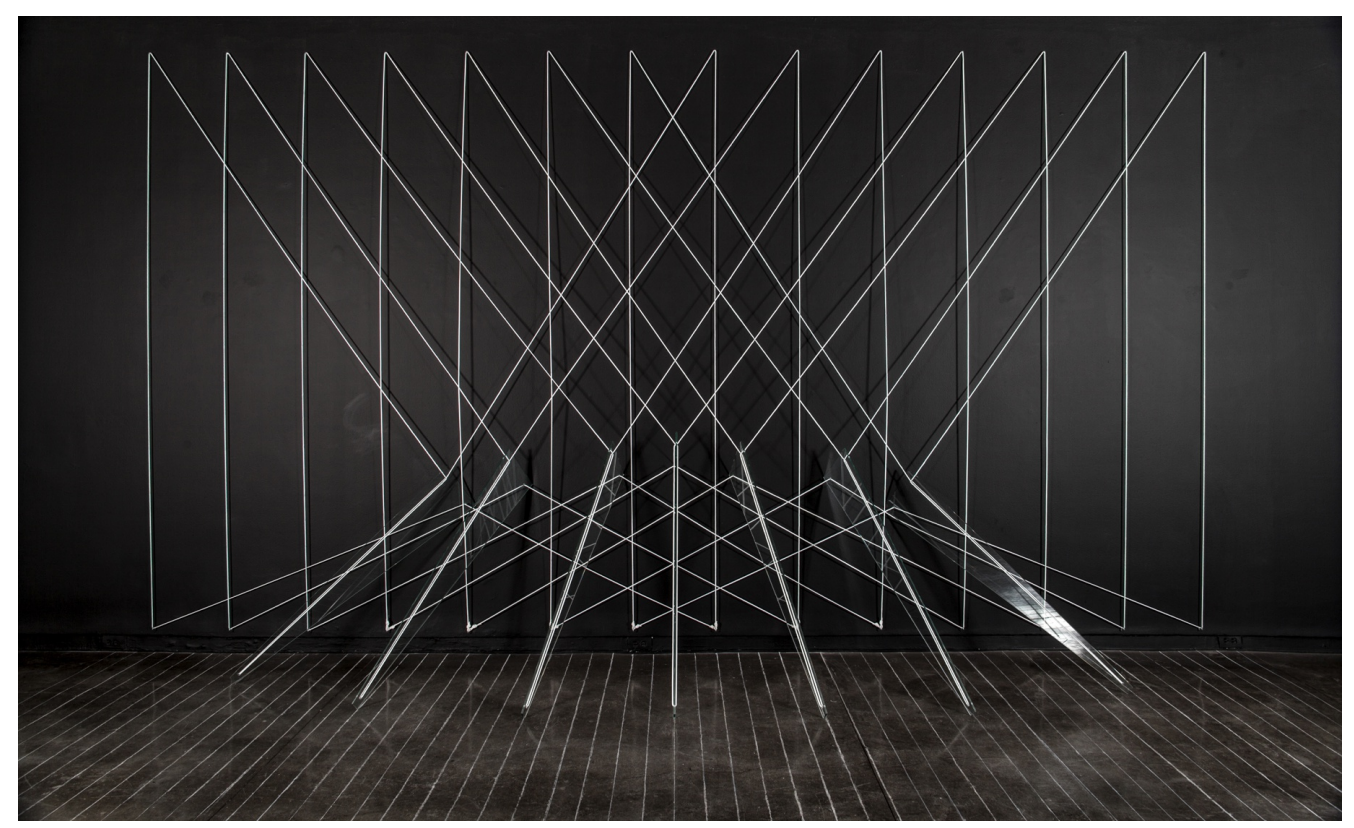

Figura 10. Lydia Okumura, In Front of Light, 1977-2015, vidrios, tornillos, cuerdas y tizas, $60 \mathrm{x}$ 220 x $110 \mathrm{~cm}$. Exposición Metáforas Construidas. Galería La Cometa, 2015, Bogotá - Colombia. Colección Esteban Jaramillo. Fotografía: Juan Pablo Velasco.

En Estudios para nueva propuestas de interpretación del espacio físico (2015), de Zignnatto, aparecen de forma literal los instrumentos idóneos para la construcción (reglas, transferidores, hojas cuadriculadas, plomada) resignificando tanto la función lógica de los mismos, como su emplazamiento espacial. La inserción de estos instrumentos en la instalación también delata, intuitivamente, los procedimientos utilizados en la construcción de la obra. La localización de la instalación promueve la interacción sensorial con los elementos funcionales de la sala de la galería, específicamente de los paneles deslizantes donde se encuentran las obras de la colección. Las tramas cuadriculadas dibujadas en la pared se confrontan visualmente con las de los paneles deslizantes en el desplazamiento por los rieles que los sostienen.

Bambozzi, por su parte, con el video Pequeñas glorias matinales (2013) registra el movimiento de sombras y luces de una habitación de su apartamento, engendradas por la luz del sol sobre los objetos que allí habitan, en intervalos continuos de tiempo. Las imágenes originadas, abstractas o no, monocromáticas o sutiles, remiten a una cámara pinhole en gran escala. De esta forma, el artista nos 
muestra el registro de una acción cotidiana, demarcada geométrica y personalmente, forzada a la apreciación. Sin dejar de compartir la intimidad del artista con el colectivo, el registro manifiesta la exploración de los mecanismos y recursos propios de la tecnología y de las leyes universales, así como el desplazamiento demarcado de la realidad documentada.

Ya en el vídeo Somnus (Noite São Guálter), de 2010, Pera explora las cavidades disponibles en cada habitación de una casa, mostrándonos cartográficamente la composición de cada aposento. En la serie Mostruário São Paulo, 2014-2015, obras realizadas con bloques de concreto, viga de aluminio, maqueta de papel, el artista enaltece la contradicción de los componentes de las piezas en sus relaciones espaciales. En los bloques de cemento en tamaño real aparece empotrada una pequeña viga de aluminio, sobre la que descansa la maqueta colorida de una ventana de algún domicilio de São Paulo, recortada en una escala muy inferior a la de la realidad. De este modo, las relaciones entre realidad y representación se vuelven contradictorias, sin que los nexos entre los materiales resulten forzados. Aquí, una vez vez más, quedan claras las relaciones propuestas en Metáforas Construidas: las contradicciones espaciales representadas en el acto plástico y visual.

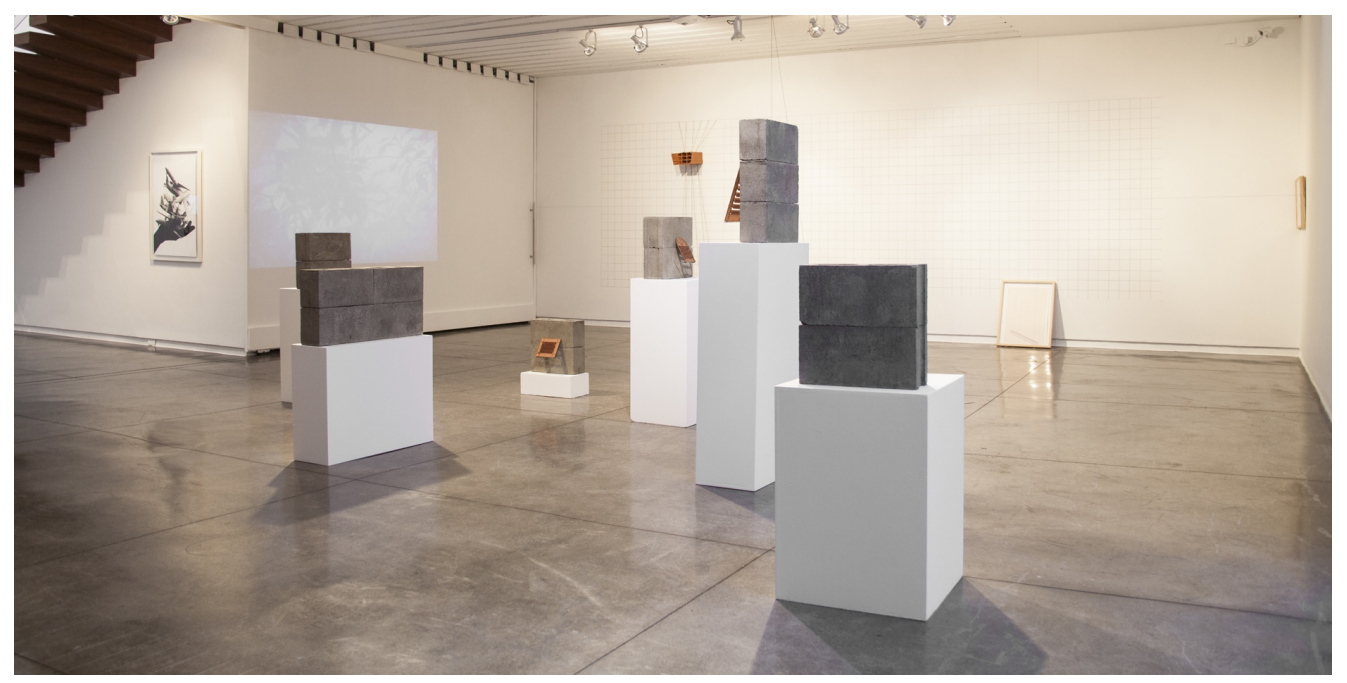

Figura 11. Vista parcial del la exposición colectiva Metáforas Construidas. Galería La Cometa, 2015, Bogotá - Colombia. Fotografía: Juan Pablo Velasco.

Al mismo tiempo que Silveira, Bambozzi y Pera argumentan con sus vídeos El arte de diseñar, Una vez más, Pequeñas glorias matinales y Somnus (Noite São Guálter), respectivamente, en su realización respetan las distancias de discusión conceptual de los procesos mecánicos y/o digitales, patentan el proceso ininterrumpido en busca de innovaciones constantes del registro cinematográfico, que permitan al espectador adentrarse en el tema de la manera más efectiva posible. Demuestran aquí que el cine ha estado en constante transformación, nunca con una fórmula absoluta, modificando y actualizando sus estructuras narrativas y la forma como interactuamos y nos sumergimos en él y con él. De tal modo, estabelecen un 
dialogo con la teoría y la practica cinematográfica, con formas novedosas de exhibición y recepción, generando un debate entre el filme, el espacio físico en el cual es representado, y el espectador. El espacio es insertado en el filme y no el filme en el espacio donde será proyectado; así se crea un ambiente, aquel en el cual el espectador va a construir su conexión con la obra de arte en un intercambio sin trayectoria definida.

Tanto las obras de Metáforas Construidas, exposición individual de Regina Silveira, como la muestra colectiva de Andrey Zignnatto, Lucas Bambozzi, Renato Pera y Lydia Okumura, ambas exhibidas en la galería La Cometa, abordan las multiplicidades del gesto en el movimiento de la representación y en la repetición del símbolo, que prevalecen nutridos de nuevos significados. Son nuevas circunstancias de lo ya significado, del símbolo con nuevas funciones. Aquí nuestros ojos penetran un conjunto de obras que encarnan la metáfora de pieles cosidas y/o proyectadas, de y para superficies, donde lo que podría ser imposible se transmuta en realidad reinventada. Ambas exposiciones se encuentran, pues, zurcidas en una relación única: pieles desnudas o protegidas, pieles con o sobre pieles, donde todos son protagonistas, no hay figurantes, ni coadyuvantes. Pieles para hacer, ver sentir, escuchar... en fin, el movimiento sensorial de lo visual concomitante con el saber plástico. Saber y disfrutar todo, verdad o fantasía. De nuestro paso por la vida lo único que prevalece es el arte con sus vestigios, construidos en temporalidades alternadas: he aquí las construcciones (las costuras) de Regina Silveira en una de las ciudades icónicas de la nueva arquitectura latino-americana: Bogotá y La Cometa.

\section{Conclusiones:}

La exposición Metáforas Construidas, sirvió como marco para revelar la diversidad de soportes, métodos e ideas de la producción plástica-visual brasileña, desde los años de 1970 hasta la actualidad. Así fueron expuestas lado-a-lado, obras pioneras en la producción conceptual, nacional, los primeros video-arte con proyecciones audiovisuales más contemporáneas, obras híbridas resultantes de la relación con el espacio expositivo, así como la materialización conceptual de relaciones predominantemente artísticas en contextos culturalmente diferentes al brasileño.

\section{Referências:}

Catálogo de la exposición Regina Silveira: desenhos. AS Studio, São Paulo, Brasil, 1995.

CRIMP, Douglas. Sobre a ruínas do Museu. Trad. F. Santos. São Paulo: Martins Fontes, 2005.

FERREIRA, Gloria; COTRIM, C.(org). Escritos de Artistas. Rio de Janeiro: Jorge Zahar editor, 2006.

HAVEY, David. A Condição Pós-moderna. São Paulo: Loyola, 1998, 14a edição, p.17. 
MILLER, Mary Ellen. El Arte de Mesoamérica de los Olmecas a los Aztecas, p.131. Editorial Diana, S.A. México, 1998.

OBRIST, Hans Ulrich. Uma breve história da curadoria. São Paulo: BEI, 2008.

THORNTON, Sarah. Sete dias no mundo Arte. São Paulo: Agir, 2010.

. O que é o artista? Rio de Janeiro: Zahar editora, 2014.

TRIGO, Luciano. A grande feira. Uma reação ao vale-tudo na arte contemporânea. Rio de Janeiro: Civilização Brasileira, 2009. 